\title{
Migration and Rural Differentiation: Evidence from a Vietnamese Village
}

\author{
Thi Minh Khue Nguyen ${ }^{1,2}$, Thi Dien Nguyen ${ }^{1}$, Thi Minh Hop $\mathrm{Ho}^{2}$, Philippe Burny ${ }^{2}$, Thomas $\operatorname{Dogot}^{2} \&$ Philippe \\ Lebailly $^{2}$ \\ ${ }^{1}$ Faculty of Political and Social Sciences, Vietnam National University of Agriculture, Trau Quy. Gia Lam, \\ Hanoi, Vietnam \\ ${ }^{2}$ Faculty of Economic and Rural Development, Gembloux Agro-Bio Tech - ULiège, Passage des Déportés, 2 \\ B-5030 Gembloux, Belgium \\ Correspondence: Thi Minh Khue Nguyen. Tel: 849-4880-8358. E-mail: nguyenthiminhkhue@student.uliege.be
}

Received: May 9, 2019 Accepted: May 23, $2019 \quad$ Online Published: May 31, 2019

doi:10.5539/ass.v15n6p106 URL: https://doi.org/10.5539/ass.v15n6p106

\begin{abstract}
This paper explores the links between migration and social differentiation in rural Vietnam after the reform period (2005-2015) through a case study of Maithon village, Chilang District, Bacninh Province. Since 2005, many villagers have left Maithon to work in cities, industrial zones or to find employment abroad. The migration process has transformed labour and income structures and supply in many households. However, 90 percent of Maithon households claimed on the positive contribution of remittance, while at the same time, they did not suffer from labour shortage due to the circular pattern of the migration. Therefore, rural out-migration is one of the diversification strategy which enables the villager to gain access to cash income in urban areas while still keep position in rural areas. It has resulted in the increase in the size of the middle class, rather than the generation of the gap between the rich and the poor. Through this process, migration becomes a developmental strategy, as a means for upward mobility rather than mechanism of social differentiation.
\end{abstract}

Keywords: migration, social differentiation, poverty reduction, rural-urban linkage, livelihood.

\section{Introduction}

Vietnam still tends to be characterized as a region where farming remains the pre-eminent occupation. Indeed, statistics shows that even Vietnam has recently experienced rapid industrialization and modernization which would lead to the diminishing role of agriculture (Bui Minh, 2012; Hoang Xuan Thanh, Truong Tuan Anh, Luu Trong Quang, \& Phuong, 2013). There has been a change in the structure of GDP whereby the share of agriculture has relative declined from 42 percent in 1989 to 26 percent in 1999 and 21 percent in 2011 while the industry sector has more than doubled from 23 percent in 1990 to 47 percent in 2011 (GSO, 2011). Despite the prediction of de-agrarianisation, agriculture is enduring (Hirsch, 2011; Peemans, 2013). The economy of Vietnam still depends on agriculture which accounts for more than one-quarter of the GDP, provides $85 \%$ of exports and employs about $60 \%$ of the work force, and a large part of the Vietnamese population (68\%) resides in rural areas which makes farming continue to be the important lives and livelihoods of many Vietnamese, especially the most vulnerable people.. In Vietnam, the Red River Delta region in the Northern part shares the common features of agrarian transition undergone by the Doimoi (Innovation Reforms) in the mid-1980s. The region's agriculture is also influenced by a range of factors including globalization, environmental and demographic changes and increased mobility. Agricultural land has been converted toward more market and industrial orientation to gain faster economic development (Nguyen Thi Minh Khue, Nguyen Thi Dien, \& Ph., 2016; Nguyen Thu Phuong, Tran Ngo Thi Minh Tam, Nguyen Thi Nguyet, \& Oostendorp, 2008). Red River Delta historically is also the densest populated region in Vietnam with average 0.04 hectares per head ${ }^{1 .}$ Therefore, since late 1990s this region witnessed a significant increase of off-farm business ever. Rural households often adopt more than one strategy to diversify their livelihood such as intensifying agricultural production and

\footnotetext{
${ }^{1}$ The area of land devoted to production agriculture accounts for $29 \%$ of Vietnam's total land area; Vietnam currently has only 0.11 hectares of agricultural land per person. This area however is distributed uneven distribution across regions. In the Red River Delta, land area for agricultural production accounts for 0.04 hectares per head. IN Mekong Delta, the average MRD people have land for 0.14 hectares agricultural land (Bui Minh, 2012)
} 
diversifying their economic activities in non-farm business. Therefore, there is a large wave of peasant migrants moving out of agriculture to find the jobs in nonfarm sectors along rural-urban continuum (Nguyen Thi Dien, Lebailly, \& Vu, 2014). The migration decision in Vietnam is clearly not only related to personal life, but also presented the rural households' strategy, therefore, migration has complicated and multi-dimensional impacts on rural households. While there is little doubt that migration would improve the well-being of migrants' households in developing country, its impact on rural inequality remains debated and less straightforward. This paper will focus on the impact of circular migration on the social differentiation in the rural areas. Circular migration has been adopted by many households ranging from the poor, the middle class to the better-off (Asis, 2006; Hein De Haas, 2010) and it has had both financial and social impacts on communities and individuals.(Hugo, 2009; Hull, 2007) Similarly, remittances have had positive effects on social resilience and rural economic growth (Hein De Haas, 2007; Seddon, 2004). The question this study seeks is to what extent has circular migration been a route to enrichment - in other word how does it contribute towards accumulation and then social differentiation? I argue that circular migration should be seen as any other diversification strategy which enables the peasant to gain access to cash income in urban areas while still keep position in rural areas. The interaction between rural and urban is emphasized through the peasant out migration. He/she still keeps a strong link with the rural area that constitutes particular contexts and in turn generates specific indicators, cause and mechanisms of social differentiation. Through this process, migration becomes a developmental strategy, as a means for upward mobility rather than coping or "survival" strategy with rural distress.

\section{Methodology}

The fieldwork was conducted in 2015 in Mai Thon Village in Chi Lăng Commune, Que Vo District, Bacninh Province in Vietnam. "Làng" was one of the most typical institutions of ancient Vietnamese society(Dũng, 2010; Gourou, 1945). Paul Mus (1952: 240) stated that "Vietnam is a network of villages" and he emphasized "it was villages that produced Vietnam and it was in them that one learned to apprehend it, at decisive times, in its national spirit" (Mus, 1952:21). Every village had its own lands, agricultural practices, its own property and its own justice, with distinct traditions, cultures, politics and economies (Khoang, 1966) Therefore, a village has been viewed as the most appropriate entry point for research into rural conditions and change in rural Asian and particularly in Vietnam studies. In this thesis, I choose Maithon as one typical Vietnamese village of Bac Ninh province in Red River Delta of Vietnam to do research. Bac Ninh is located in Red River Delta, about 30km far north from the capital Ha Noi, along the recently upgraded National Highway 1A. Red River Delta region of Vietnam shares the common features of agrarian transition undergone by the Doimoi Reform. Agricultural land has been converted toward more market and industrial orientation to gain faster economic development. According to the recent National Survey on Land, in a decade from 2000 to 2010, the non-agricultural land increased 89000 hectares while the land for rice production decreased more than 34000 hectares annually (Nguyễn Ngọc Công, 2012). The overall number of landless farmer households in the region was 3.3 percent in 1999, 13.9 percent in 2002 rose up to 22 percent 2012 (FAO, 2014). Red River Delta historically is also the densest populated region in Vietnam with average 0.04 hectares per head ${ }^{2}$. Therefore, since late $1990 \mathrm{~s}$ this region witnessed a significant increase of off-farm business ever. Rural households often adopt more than one strategy to diversify their livelihood such as intensifying agricultural production and diversifying their economic activities in non-farm business. It is noteworthy that this area have a good infrastructure and transport link allows people to seek employment in the capital Hanoi and other local urban centers without the need of leaving their hometown permanent.

Sharing the same characteristic with other villages in Red River Delta, Maithon was chosen because firstly this village has experienced dramatically change due to modernization process of Doimoi, in which the high level of migration is one of fundamental characteristics (Rigg \& Vandergeest 2012). Secondly, Maithon socio-economic conditions are characterized by monoculture in rice production and before its first high wave of temporary migration in 2005, the village population was mainly leaned on farming as the only source of income. Until now, it is considered as the lowest on economy status due to having no industrial zone, no traditional handicraft as other villages, and very limited dynamic non-farm business diversification and at far distance from capital of province $(30 \mathrm{~km})$. Thanks to its mono-source of earnings in rice production, the Maithon household income in 2005 could be recalled based on their agricultural land areas which had statistics record. Besides, monoculture gives me a chance to isolate the impact of circular migration with the rural areas from other factors.

\footnotetext{
${ }^{2}$ The area of land devoted to production agriculture accounts for $29 \%$ of Vietnam's total land area; Vietnam currently has only 0.11 hectares of agricultural land per person. This area however is distributed uneven distribution across regions. In the Red River Delta, land area for agricultural production accounts for 0.04 hectares per head. IN Mekong Delta, the average MRD people have land for 0.14 hectares agricultural land (Bui Minh, 2012)
} 
A sample of households was selected by conducting a stratified sampling method. This first involved acquiring the complete list of households (hokhau record ${ }^{3}$ ) that supply basic characteristics of village. I selected migrant and non-migrant households using the very detailed hokhau records of the village which the village cadres scanned and sent via internet. Of 558 households in the village, 235 (42 percent) households are recorded to have at least one member current circulate out. Of 323 non-migrant households, it should be noticed that some may have members who migrate for education. I identified these household into the non-migrant households because they are not involved in labour circulation. Other cases are some non-migrant households which had previous had members migrating out but now returned and engage in some non-farm business. These post-migrant households, however, are only 2 households according to the village cadres. Estimating this strata is not enough to supply a sample to compare with not-yet migrant households and recent migrant households. Therefore I put them into non-migrant households and investigate them as case study only. Besides, it should be noticed that the non-migrant households probably have members renting out labour within the village and the province. However, they are commuting back and forth every day then I excluded them out of migrant household strata.

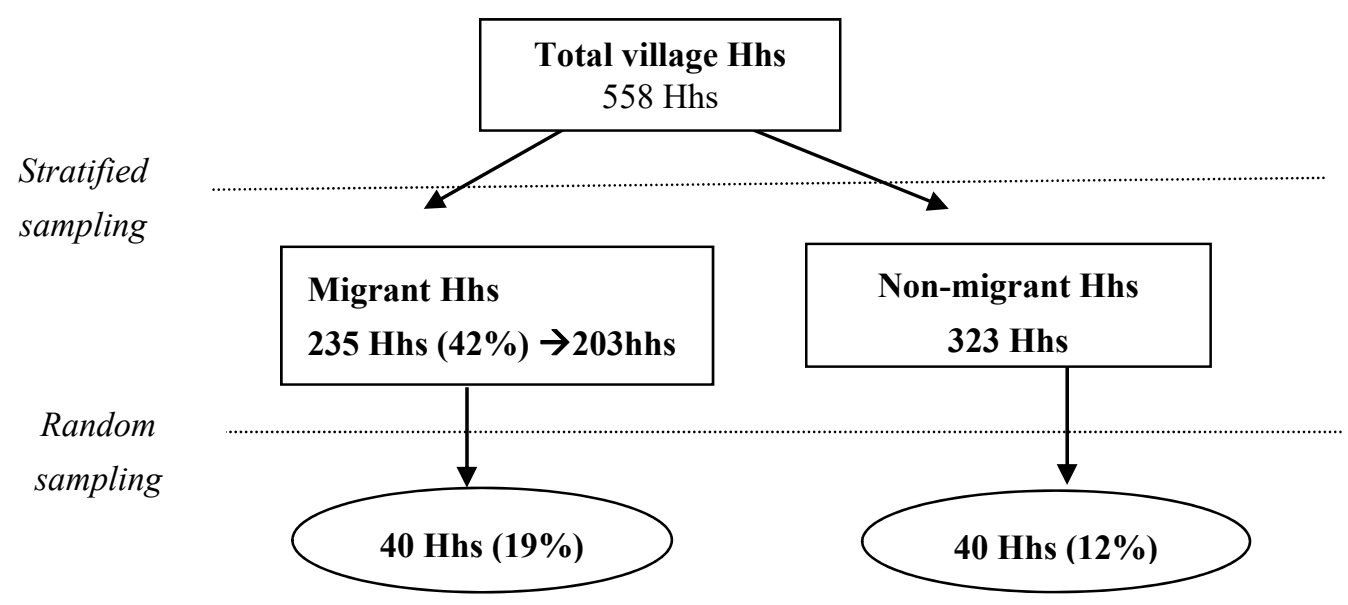

Regarding to migrant households, I first identified the households which had migrated their entire family ${ }^{4}$, which is 23 out of 235 households by consulting the village cadres who know exactly about the demography in the village. Of 212 migrant households which still have member at home for interview, I took one more step to identify which family had member migrate before 2005 as first year. There are limited number of household joined into this strata and this first generation during the years of 1990s mostly remains permanent in the place of origins. The second generation who keeps circular mostly started in the year 2005 forward. Of the 203 households, I used a random sampling procedure. I chose 40 interviewees from every 5 interval from the list of migrant households and every 8 interval from non-migrant households. It should be noticed that 40 migration households included 53 migrants which will be analyzed in the Table 3.1, 3.2.

\section{Findings and Discussion}

\subsection{The Cause of Differentiation}

\subsubsection{Migration's Selective}

The characteristics of migrants which are important to the effect of migration on the economic development in the place of origin will be discussed on this section. Maithon has 538 households in which around 235 households have at least one or more than one member who has migrated out for work. Circular migrants in this village share characteristics with migrants from other regions in Vietnam. They are typically young, relatively well-educated men when compared with the rest of population and the migrant households tend to be a bit larger

\footnotetext{
${ }^{3}$ Ho khau refers to the system of residency permits which dates back 1950s, which is closely related to other benefit such as agricultural land contribution, housing, education, administrative papers and even food in the collectivization period. A hokhau can also refer to a family register in many contexts since the household registration record is issued per family, and usually includes the births, deaths, marriages, divorces, and moves of all members in the family.

${ }^{4}$ It should be noticed that even though from these households migrates the entire family they are not permanent migration because they haven't cut their hokhau and keep returning intention. In most cases these entirely migrated households still have the children (all or few) be left in their "hometown" with their grandparents. However, they are usually too small to be interviewed.
} 
than other households. In sample survey migrant household have generally 5.4 members versus 4.7 members for non-migrant ones. Table 3.1 presents the age of the migrants as being pretty young, the percentage of migrants below 30 years of age is almost half which seems to corroborate the argument mentioned above on the Land Law 1993, which is that the young labour force becomes surplus in the rural areas where land distribution is already fixed. Instead of waiting for the next redistribution they therefore choose to migrate out. The migrants' ages are relatively young although the survey only conducted on their present age. The number would be higher, had the survey taken at the time of the first migration (with the elder migrants usually moved more than 10 years ago).

Table 3.1 Age and gender of the migrants

\begin{tabular}{cccccc}
\hline \multicolumn{2}{c}{ Present age of the migrants } & \multicolumn{3}{c}{ Present gender of the migrants } \\
\hline \multirow{2}{*}{ Age } & $\begin{array}{c}\text { Number } \\
(N=53)\end{array}$ & Percentage & Gender & $\begin{array}{c}\text { Number } \\
(N=53)\end{array}$ & Percentage \\
\hline $20-30$ & 23 & 43.4 & Male & 47 & 88.6 \\
$31-40$ & 12 & 22.6 & Female & 6 & 11.4 \\
Above 41 & 18 & 34 & & & 100 \\
Total & 53 & 100 & & 53 & \\
\hline
\end{tabular}

Source: household survey 2015

Regarding the education levels, the average migrant in the sample had 9.6 years of schooling, while non-migrants have an average of 7.4 years of schooling. These results are similar to early studies of migrants in Vietnam from macro level studies (Coxhead, Nguyen, \& Linh, 2015; Dang, 2006) which shows that migrants comparatively well educated. The next generation of migrants (usually young individuals) have higher years of education than the earlier ones, which can easily be from understanding of the general national development that occurred in education. Particularly, among 6 female migrants, 5 already finished high schools (12/12), which is relatively high compared with the rest. Female is likely need more human capitals to access the migration chance.

Table 3.2 Education of the migrants

\begin{tabular}{ccc}
\hline Education level & Number of migrant $(\mathrm{N}=53)$ & Percentage \\
\hline Illiterate & 0 & 0 \\
Primary $(5 / 12)$ & 0 & 0 \\
Secondary $(9 / 12)$ & 42 & 79 \\
High school $(12 / 12)$ & 11 & 21 \\
Above & 0 & 0 \\
Total & 53 & 100 \\
\hline
\end{tabular}

Source: household survey 2015

One important aspect is that the migration decision-making is usually not an individual's decision rather it is made through the consensus of the whole family. Even though the migrants made decision by themselves, the ideas of the family members such as parents, brothers, relatives and particular spouses are more appreciated. It indicates that circular migration is adopted by most households as a household strategy rather than an individual response. This point was stressed by both migrants and the people left behind in almost interviews and discussions. The migrants explained because firstly they need support from family and relative to help in agricultural work and housing care. In most cases, the arrangement of household labour allocation is organized before a family member migrated out. Secondly, when the migrants have the family support, they will more easily access to the social network which mostly based on the kinship. Social network is an important aspect that minimizes the movement costs and risks, and hence it seems to be fundamental factor influencing decisions to migrate (Khuat \& Le, 2008; Lall, Selod, \& Shalizi, 2006). Circular migration in this locality is mostly based on the strong social networks that have already been built from the first migrant generations (Deshingkar, 2006). The villagers mostly circulate whenever they are ensured about the work (majority is in the informal sector such as making lime, doing construction for males and domestic servant for females) and their living place. Given that, it is not surprising that circulation involves more poor strata than any other strata. 


\subsubsection{Remittance Characteristics}

As a household economic strategy, remittance plays an important role in circular migration purposes in the village. The volume and frequency of remittances sent back are largely determined by the level of income earned at the destination and the commitment within households. (De Haan \& Rogaly, 2015; Hein De Haas, 2009). In the survey, it was found that due to the active social network, the security of the migrant's job has a positive impact on the remittance behaviour. It is imperative to notice that there is often a counter flow of money and commodities involved in migration. As migrants at destination are at beginning dependent on their social network for their basic needs. If they lack food or income, they are often supported by their rural households from back home. Normally, the migrant's household also invested for their first transportation (dependent on the distance to the place of destination) and the cost for settle down. The migrants reported that thanks to relative support they would save and remit more than those without such support. Even though the amount of money depends on level of income individuals earn, most migrants report that they remit half of their income home.

The remittance fluctuates dramatically from two million VND to five million $\mathrm{VND}^{5}$ per month. Table 3.3 shows the remittance levels in this locality, divided remittance basically into three groups: 1 . Under 2 million VND per month, 2. From 2 to 5 million VND per month and 3. Over 5 million VND per month. The first group mostly falls into the household in which the first son has already married but still registers under the same hokhau with his parent and circulates out. They send very limited money back to their parent, however, this cannot tell exactly amount of money that they send home, possibly for their wives (who still living in the same dwelling) to take care of their own children. Because the interview is taken with only one member of household, usually the head of household and in most case it will be the eldest male in the family; it cannot capture exactly the inflow of remittance. The third group mostly falls into the households which have member migrate to the South. Migration to the Southern part such as Ho Chi Minh or Binh Duong city tend to earn the higher income compared with other cities within the countries due to its economic development. Two million Vietnam dong is nearly tripled the average income from agriculture for each person per month in the village. A majority of migrants indicated that they benefited from their circulation and earn more than they could in agricultural work. In the village, 83.5 percent of correspondents preferred to have the family member migrate out and send remittance rather than staying put in the village.

Table 3.3 Remittance level per month

\begin{tabular}{ccc}
\hline Remittance level & Number of households \\
(unit: million VND) & $(\mathrm{N}=40)$ & Percentage \\
\hline Under 2/ month & 11 & 27.5 \\
$2-5 /$ month & 23 & 57.5 \\
Over 5/ month & 6 & 15 \\
Total & 40 & 100 \\
\hline
\end{tabular}

Source: household survey 2015

Moreover, one of the remarkable features of remittance in this village is its stability and frequency, which is likely due to the close relationship between the migrants and the family (which will be discussed below). 90 percent of households who reported that they received remittances claimed the frequency of remittance every year. The timing of receiving money in each year however was found to depend upon on the distance and the social networks which permit them to visit or send money home. Recently, due to the development of bank service in rural areas, some migrants sent remittance through bank accounts for their family member to receive. A stable financial inflow was one important characteristic of remittance which ensures the sufficient cash. In contrast with agricultural income which is mainly dependent on the weather and market, remittance strengthen the peasants' livelihoods security and rural household autonomy (Nguyen, Le, Burny, \& Lebailly, 2018) and makes circular migration becomes a preferable choice (GSO, 2011)

\subsection{Remittance Usage: The Mechanisms of Differentiation}

Although the amount of remittances from migrants tends to be small, they remain a very crucial financial source for sustaining households. Table 3.4 shows the correspondent's multiple purpose of using remittance. It is important to notice that there is a gap between their intended usages with their real usage of remittance. Another crucial point is that table 3.4 only reveal the number of people when choosing the remittance purpose, it does not

\footnotetext{
${ }^{5}$ Equivalent to from $\$ 100$ to $\$ 250$ per month in 2015
} 
reveal the level of importance of each purpose. For example, if the household have sick or old members, they will devote remittance for health care first and foremost. However, due to the sample size, only 15 correspondents reported using remittance for this purpose. Whether remittances are used for productive purpose or not is always at the heart of the debate. My survey data shows that the share of households which use remittances for productive investments, especially in agricultural production, is relatively large. 67 percent of the correspondents indicated that they had invested in agriculture production. Further in-depth interviews show that 80 percent of the migrants' households receiving remittances planned or actually did invest productively in rice productions or in machinery (for instance hand pumps). However, due to the gap between the intention of remittance usage and the actually use it needs to investigate more to what extent remittances have encouraged risk-taking and have supplied credit for expanding agricultural production.

Table 3.4 Intended purpose of remittance usage (multiple choice)

\begin{tabular}{ccc}
\hline Purpose of remittance use & $\begin{array}{c}\text { Number of hhs } \\
(\mathrm{N}=40)\end{array}$ & Percentage \\
\hline Invest in agriculture production & 27 & 67.5 \\
Education & 22 & 55 \\
House improvement and consumption & 18 & 45 \\
Heath care & 15 & 37.5 \\
Invest in non-farm activities & 10 & 25 \\
Others & 9 & 22.5 \\
\hline
\end{tabular}

Source: household survey 2015

The main uses of remittance in this village I already conducted after the focus group included: house improvement and consumption, agriculture investment, health care, debt reimbursement and education. The table 3.4 shows agricultural investment as the most common (67 percent) while education is second (55 percent) and house improvement and consumption is third (45 percent). However, when combining with result from the survey about household consumption and reports that the interviewers observed from the field, it shows that the remittance is actually firstly used for household consumption to improve housing and living conditions of the family, followed by better access to health and then education services. However, although all household classes use remittances for daily consumption, rich households tended to invest more on consumer durables, tools, and means of transportation while the poor strata use the extra funds for housing, debt reimbursements and health care. Regarding to education purpose, twenty two correspondents who chose that purpose are all the households in sample survey who had children still at school age. All of them indicated that they devoted most remittance for their children education. Even in some cases, their living standard is subsistence; they did attempt to invest in children education. It is possibly considered as long-term investment in human capital which would result in long-term patterns of differentiation as suggestion by

The impacts of remittance on the rural society are much more complicated than the current simple economic view (H. de Haas, 2005; Tran, 2010). In Maithon village, remittances have a social as well as an economic function; they are not only a mean to maintain or improve economic status but also a mean to achieve higher prestige and standing in the local community and family for instance by spending part of remittances on ceremonies or local amenities. In sum, with substantial flows of remittances, in one direction or other or in both, it is likely to have affected income distribution, which has had an accelerating or facilitating technological change, altering the division of labour and through these mechanism increasing class differentiation, which are discussed in the proceeding sections.

\subsection{Indicators of Differentiation}

Income and consumptions

With the intention of earning money, circulation is expected to contribute remarkably to income and living standard. Eighty percent of the sampled households specified that the balance of their household budget has unchanged. According to them, there was no change due to the increase in consumption. However, they admitted the steady improvement in the household income. While 17.5 percent reported that their income exceeded to their prior levels, only 3.5 percent indicated that their income have deteriorated due to their sickness or husbandry disease.

In terms of consumption, the upward trend is discovered and 100 percent reported that it has increased 
remarkably over ten years in both agricultural production cost and daily consumption cost. Particularly for educations, if household has children of school going age, then it is the most costly item in consumption list, even more than the whole household food per year. Regard to migrant households, given husbands had mostly migrated out, the interviewees were wives who knew clearly about the household food consumptions. In most cases, they reported that thanks to their husband's remittance, the daily meals have been changed with more nutrition when it is supplement with more egg, fish or meat rather only rice and vegetable as before. In the migrant households, the living standard is seen to be lifted up due to circular migration. Figure 3.1 also presents the Lorenz curves ${ }^{6}$ of income distribution of sample households in 2005 and 2015. The Gini index in 2005 was 0.45 while it slightly reduced to 0.417 in 2018 . This reveals the social differentiation slightly decreased in the research village.

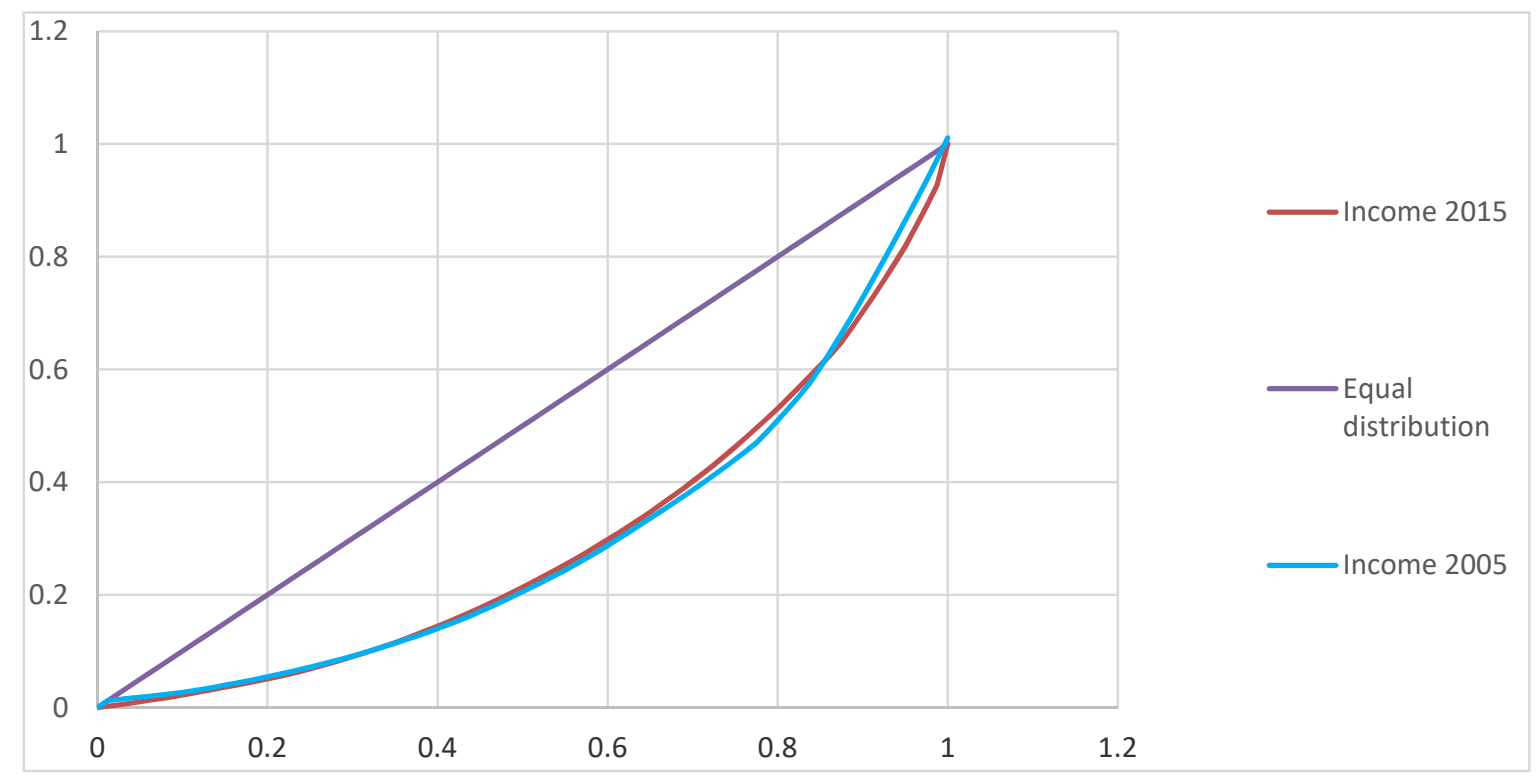

Figure 3.1. Income distribution before and after migration

Source: Household survey, 2015

\section{Wealth indicators and strata}

The focus group discussions helped me to categorize the sampled households into 5 strata. Data from my survey also reflects the same results about the household by stratum. Table 4.5 reveals that in 2015 , the migrant sampled households mostly fall into the stratum 3, while interestingly none belong to the first and the last stratum. At the same time, non-migrant sampled households are more spread out and fall into the stratum 4 . In contrast with the migrant households, they have 5 households (12.5\%) which belong to stratum 1 and also 7 households (17.5\%) belonging to the last stratum. This phenomenon corroborates with the analysis in the part 3.1 that the non-migrant households fall mostly in the richest and poorest quintiles. Primarily because the very rich were found to be more focused on other non-farm businesses rather than on circulating out while the very poor households possibly have limited chance to migrate out.

Table 3.5 Percentage of households by stratum, 2015

\begin{tabular}{cccccc}
\hline & Very rich & Rich & Ordinary & Poor & Very poor \\
\hline Migrant household $(\mathrm{N}=40)$ & 0 & $32.5 \%$ & $52.5 \%$ & $15 \%$ & 0 \\
Non-migrant household $(\mathrm{N}=40)$ & $12.5 \%$ & $7.5 \%$ & $10 \%$ & $52.5 \%$ & $15.5 \%$ \\
\hline
\end{tabular}

Source: household survey 2015

\footnotetext{
${ }^{6}$ Applied the formula of Simpson's rule error bound, the results of error bounds are calculated as below:

Es $(2005)=0.0842$ and Es $(2015)=0.0845$. The small error bound values show the well reflection of household income distribution which are presented in Lorenz curves.
} 


\section{Box 3.1: An upward mobility case}

Mr An is 32 years old. He finished high school in 2002, and then pursued the electrical repair training in the vocational school. When studying in Hanoi, he also joined with the villager to be motorcycle driver to gain extra income which would be around 50000 Vnd per day. This amount of money in that day was enough to cover his own living cost, and his parents only needed to pay the school fee. After 2 years of training, he came back to do farming and part-time job while waiting for decent work. Until 2009 he had opportunities to be a driver in Que Vo Industrialized zone. His work recently is not really hard even though he still need to work by shift: one week in the day time and other week in the night time. He normally works nine hours per day and receives 9 million Vnd per month which is relatively high in comparison with other jobs. Moreover, he was also covered with social insurance and having extra bonus when he went to work far. He is now living in Bacninh city which is around $30 \mathrm{~km}$ from village with his wife who is running a clothes shop in the town center. They both prefers migrating until their parents cannot take care of the paddy field...

(Interview 2015)

Analysing from the political economy perspective of peasant movements, it is seen that migration appears not to have led to the proletarialization of the peasantry as de Haan (1994) has suggested; rather migrants were not helplessly forced into migration, but chose to do so. Migration has instead been found to be a part of a diversification strategy to "keep a foot on the farm", as the migrating peasant labour "hybrid features: peasant workers and urbanized villagers" (Lebailly Ph., J.Ph. Peemans, \& Vu D.T., 2015). According to the 2009-2010 peasant survey, in the Northern rural areas of Vietnam there exist very few peasants who work full time as farmworkers, (Bùi Quang Dũng 2011: 17). It is interesting to notice that Mai Thon villagers who could not participated in migration may use their spare time knitting sedge bags for sale. The average income of votive weaving falls into 1-2 million VND per month. Although this income is not too high, but people prefer because they can stay at home and take advantages of un-productive labor resources help as the elderly and young children. Therefore, there is about $50 \%$ of households Mai Thon village participating in votive weaving. Such an approach rules out the importance of "multiple job holding" (van der Ploeg \& Jingzhong 2010), or "occupational multiplicity" (Breman 2007) or "diversified livelihoods" (Ellis 2000; Krishna 2006; Lahiri-Dutt 2014; Scoones 2009). In other words, circular migration is therefore found to be simply a good choice in the peasants' livelihood portfolio, to diversify their incomes through low investment providing stable income while "guaranteed some land for their livelihood." Maithon shows the same picture with other rural household in Red River Delta that majority of them cannot be referred to as "farming households" but instead as "rural households which continue to farm" (Nguyen Thi Dien et al., 2014; Nguyen Thi Dien, Nguyen Thi Minh Khue, Le Thi Minh Chau, \& Lebailly, 2015). Migrating peasant labourer are able to be simultaneously peasants and labourer at the same time.

\section{Conclusion}

In this paper we have tried to show the multiple ways in which the increasing importance of nonfarm and migrant employment have influenced the lives and livelihoods of rural households in a particular commune in Central Vietnam. In this paper, circular migration in Vietnam has been defined with the main intention of earning money and returning, having closed relationship with the place of origin and hence sending remittance frequently. The emergence of circular migration has been analysed in the context of national economic transition and local specifics. The relationship of circular migration with social differentiation has been analysed through the framework that includes the cause, the mechanism and the indicators. The role of circular migration has been explored mostly from rural household perspective in the place of origin. Although this study is limited generalization of findings due to the research site, it provides a new point of view on circular migration and social differentiation in rural areas of Vietnam. Sharing the same characteristics with other village in Red River Delta, Northern of Vietnam, results from survey in Maithon village shows a typical picture of a village transformation under the impacts of Renovation Process which resulted in high level of rural circular migration. Circular migration appears to be a development strategy - as a means for improvement - in other words, a mechanism for upward mobility - rather than a "coping" or "survival" strategy in the face of declining income of livelihood collapse. And hence, circular migration is seen to have the greatest effect on the middle classes in the rural areas, rather than on the richest or the poorest strata. It has resulted in the increase in the size of the middle 
class, rather than the generation of the gap between the rich and the poor. The study shows that circular migration has a positive relationship with remittance and labour division in the village. On one hand, even though the amount of remittance tends to be small, it remains a crucial financial source for improving household living standards. It is also reliable and frequent, providing s steady income source. On the other hand, it was seen that there were no remarkable labour deficit as a result of the migration. The better management in household labour allocation permits rural households to release family members migrate to urban areas to earn cash income and at the same time extend agricultural production in rural areas.

Migrant households were managing to accumulate and invest, thereby also diversifying and strengthening their economic base. Moreover, as remittance was found to be also devoted to education purposes, it played a significant role in raising the human capital, which in long-term will possibly contribute to the improvement of the rural society. Therefore, circular migration has been adopted as a way to sustain and improve rural household status. Moreover, it has become a means for rural households to integrate in-to the urban economy. This allows the peasant on one hand to still keep their foothold on their own land and village and on the other hand, they can also gain access to cash income in urban areas. Investigating circular migration, from the rural perspective, has therefore provided insights and evidence to reconfirm the important role that it plays in development.

\section{Acknowledgments}

Authors wish to thanks the ARES-CCD (Academie de Recherché et d'Enseignement Superieur) for sponsoring this study.

\section{References}

Asis, M. M. B. (2006). Living with migration. Asian Population Studies, 2(1), $45-67$.

Bui Minh, B. Q. N., \& Phuong, D. T. V. (2012). Agricultural land, peasant and rural development. Sociology, 3(119), 26-33.

Coxhead, I., Nguyen, V. C., \& Linh, H. V. (2015). Migration in Vietnam: New Evidence from Recent Surveys. World Bank.

Dang, N. A. (2006). Viet Nam Internal Migration: Opportunities and Challenges for Development. Paper presented at the Regional Conference on Migration and Development in Asia, Lanzhou, China.

De Haan, A., \& Rogaly, B. (2015). Labour mobility and rural society. Routledge.

de Haas, H. (2005). International migration, remittances and development: myths and facts. . Third World Quarterly, 26(8), 1269-1284.

De Haas, H. (2007). Remittances, migration and social development. A conceptual review of the literature.

De Haas, H. (2009). Remittances and social development. Financing Social Policy (pp. 293-318): Springer.

De Haas, H. (2010). Migration and development: A theoretical perspective 1. International Migration Review, 44(1), 227-264.

Deshingkar, P. (2006). The role of circular migration in economic growth. Agri-culture and rural development, 54-56.

Dũng, B. Q. (2010). Làng xã: Dẫn vào một nghiên cứu về các thể chế xã hội (Village: Introduction to a research of social institutions). Tạp chí Xã họi học (Review of Sociology), 1(109), 11-26.

Gourou, P. (1945). Land Utilization in French Indochina. Institute of Pacific Relations.

GSO. (2011). Migration and Urbanization in Vietnam: Patterns, Trends and Differentials. Hanoi: GSO.

Hirsch, P. (2011). Afterward: Re-agrarianisation or repositioning agrarian. In C. W. Vaddhanaphuti (Ed.), Revisiting agrarian transformation in the greater mekong subregion: New challenges (pp. 185-188). Chiang Mai: RCSD.

Hoang Xuan Thanh, Truong Tuan Anh, Luu Trong Quang, \& Phuong, D. T. G. a. D. T. T. (2013). Food security in the context of Vietnam's rural-urban linkages and climate change. In IIED (Ed.). London, UK: International Institute for Environment and Development.

Hugo, G. (2009). Best Practice in Temporary Labour Migration for Development: A Perspective from Asia and the Pacific. International Migration, 47(5), 23-76.

Hull, J. (2007). Migration, Remittances and Monetization of Farm Labor in subsistence sending areas. . Asia Pacific Journal of rural development, 16(4), 451-484. 
Khoang, P. (1966). Luoc su che do xa thon o Viet Nam. A summary history of the village-hamlet system in Vietnam. Su Dia, 34-51.

Khuat, T. H., \& Le, B. D. (2008). Migration and social protection in Vietnam in the market transformation. Hanoi: World Publisher.

Lall, S. V., Selod, H., \& Shalizi, Z. (2006). Rural-urban migration in developing countries: A survey of theoretical predictions and empirical findings. The World Bank.

Lebailly, Ph., Peemans, J. Ph., \& Vu, D.T. (Eds.). (2015). Rural development and small farmers in South East Asia: Lessons of experiences in Vietnam and Cambodia. Le GRAESE (Groupe de Recherches sur l'Asie de l'Est et du Sud-Est).

Mus, P. (1952). Vietnam: a nation off balance. Yale Review, 41, 124.

Nguyen, T., Le, T., Burny, P., \& Lebailly, P. (2018). Leaving the Village but Not the Rice Field: Role of Female Migrants in Agricultural Production and Household Autonomy in Red River Delta, Vietnam. Social Sciences, 7(10), 202.

Nguyen Thi Dien, Lebailly, P., \& Vu, D. T. (2014). Agricultural land conversion for industrialization: Livelihood along rural-urban continuum and mechanism of social differentiation in Hung Yen province, Vietnam. In Lebailly Ph., J. P. Peemans \& V. D.T. (Eds.), Rural development and small farmers in South East Asia: lessons of experiences in Vietnam and Cambodia: GRAESE: Groupe de Recherches Asie de l'Est et du Sud-Est.

Nguyen Thi Dien, Nguyen Thi Minh Khue, Le Thi Minh Chau, \& Lebailly, P. (2015, December 10-11). Duality of migrant lives: Gendered migration and agriculutral production in Red River Region, Vietnam. Paper presented at the 9es Journees de Recherches en Sciences Socials, Nancy.

Nguyen Thi Minh Khue, Nguyen Thi Dien, \& Ph., L. (2016). Agricultural Production in the context of Industrialization and Food Security in Vietnam. AGROFOR International Journal, 1(1), 86-94. https://doi.org/ 10.7251/AGRENG1601086N

Nguyen Thu Phuong, Tran Ngo Thi Minh Tam, Nguyen Thi Nguyet, \& Oostendorp, R. (2008). Determinant and Impact of Migration in Vietnam. In T. D. w. p. series (Ed.), Working Paper Series No. 2008/01. Amsterdam.

Peemans, J. P. (2013). A political economy of rural development in South East Asia in relation with the many versions of the disappearance of the peasantry. Louvain la Neuve: Centre d'Etudes du Développement, UCL.

Rigg, J., \& Vandergeest, P. (2012). The restudy "problem" and agrarian change: Revisiting rural places in Southeast Asia. In J. V. Rigg, P. (Ed.), Revisiting rural places: Pathways to poverty and prosperity in southeast Asia (pp. 1-24). Hawaii: University of Hawaii Press.

Seddon, D. (2004). South Asian remittances: Implications for development. Contemporary South Asia, 13(4), 403-420.

Tran, N. M. T. (2010). Gender and remittances of migrant workers.

\section{Copyrights}

Copyright for this article is retained by the author(s), with first publication rights granted to the journal.

This is an open-access article distributed under the terms and conditions of the Creative Commons Attribution license (http://creativecommons.org/licenses/by/4.0/). 